\title{
A brand within a brand: an integrated understanding of internal brand management and brand architecture in the public sector
}

\section{$\underline{\text { Abstract }}$}

Branding in the public sector is emerging as an interesting area of research, as diverse organisations find themselves using branding principles to promote a consistent, clear brand. However, very little is known how public organisations could, or should, manage their brands. The purpose of this research, therefore, is to explore brand management processes in the public sector, and its implication for brand architecture, from an employee perspective. With a qualitative approach the study argues that branding is important not only for the organisation, but for individual departments. Further, unlike branding in the private sector, public organisations may be more concerned with supporting a positive perception and organisational attractiveness rather than a unique and differentiated brand. This may have implications for brand architecture. By allowing individual departments to manage their brand with support from organisational structures that provide alignment and focus, organisations can form a brand architecture that supports a strong organisational brand and employee brand commitment.

Keywords: brand management, brand architecture, internal brand management, public organisation, public sector 


\section{INTRODUCTION}

Branding has increasingly permeated the public sector and become a consideration for organisations within a diversity of its sub-sectors, including universities (Dholakia and Acciardo, 2014), healthcare (Sataøen and Wæraas, 2015), libraries (Hood and Henderson, 2005), and municipalities (Wæraas et al, 2015). Further, signs of greater corporatisation and brand harmonisation have emerged where sub-departments are aligned with the organisational brand and brand values (Dholakia and Acciardo, 2014; Hemsley-Brown and Goonawardana, 2007).

Alignment may in part be based on the visual identity of the brand, e.g. logos and style guides. It also puts focus on the identity and values of the organisation to define 'who' the organisation is (Balmer, 2010; Hatch and Schultz, 2009). Aligning the organisation around this identity and values is considered necessary to support a strong organisational brand (Hatch and Schultz, 2009; Harris and de Chernatony, 2001). A brand strategy that encompasses the whole organisation is necessary; departments need to work together to support a brand that is embedded in the behaviour and people of the organisation (de Chernatony and Cottam, 2009).

The organisational brand is a means to promoting an "umbrella image" for the organisation that "casts one glow over an array of products" (or services) (Hatch and Schultz, 2001). From a brand architecture perspective this "umbrella image" may parallel that of a branded house, i.e. where all individual products and services are coated in the organisational brand (Aaker and Joachimsthaler, 2000). Brand architecture describes the hierarchal structure of brands within the organisation, and the relationship between the brands (Brexendorf and Keller, 2017; Aaker and Joachimsthaler, 2000). However, existing research has mainly taken a consumer market, private sector perspective (e.g. Brexendorf and Keller, 2017; Aaker, 
2004; Rajagopal and Sanchez, 2004). In the public sector only three papers have been identified relating to brand architecture (Dholakia and Acciardo, 2014; Hudson, 2009; Hemsley-Brown and Goonawardana, 2007).

Branding is arguably a relatively new development in the public sector, but studies suggest that existing brand management theories and models may not be fully transferable to this context (Dean et al, 2016; Hytti et al, 2015; Chapleo, 2010; Wæraas and Solbakk, 2009) Further, branding in public organisations may meet resistance from internal (Hytti et al, 2015; Sataøen and Wæraas, 2015) and external stakeholders (Färlin, 2016; Westin, 2016; Whelan et al, 2010). This is troublesome as a strong organisational brand is dependent on a unified perception of the brand among various stakeholders. If existing brand management theories and models are insufficient for the public sector while branding efforts at the same time may meet resistance, understanding how public organisations should manage the brand is key.

The purpose of this paper is to explore brand management processes in the context of the Swedish public sector, and its implications for brand architecture. A fundamental question is how an efficient and successful brand process can be supported within public organisations, characterised by its complex nature and environment. To answer this question this paper explores the perspectives of employees and middle managers. While a top management view can provide insights into how a brand is managed, an employee perspective offers an opportunity to understand how branding efforts are received and understood. This research therefore provides important managerial implications of how the public brand should be managed to ensure success in the public sector. Further, it has theoretical implications within the areas of brand architecture and internal brand management. 


\section{THEORETICAL FRAMEWORK}

\section{Brand management}

As a symbol of the functional and emotional values (de Chernatony, 1999), brands have a fundamental role to play for private and public organisations alike (Dholakia and Acciardo, 2014; Gromark and Melin, 2013). While traditionally used as a means of differentiation, or an attempt to gain a competitive position (Dholakia and Acciardo, 2014; Bélanger et al, 2007), differentiation and uniqueness may not be the main objective of branding for many public organisations (Sataøen and Wæraas, 2015), nor may it be easy to achieve (Clayton et al, 2012; Chapleo 2006; Caldwell and Coshall 2002). Public organisations may have difficulty finding a unique message where communication tend to be characterised by a "sea of sameness" (Clayton et al, 2012). This 'sameness' may be linked to a sector-specific branding issue; a recent study within the hospital sector in Norway shows that for many organisations, differentiation may have little or no role in branding. Rather, protecting the egalitarian values of the sector was considered central (Sataøen and Wæraas, 2015). Further, national policies and institutional logics may be creating a focus on solidarity and interrelatedness between organisations within the healthcare context (Sataøen and Wæraas, 2015). Branding therefore becomes more about conformance and being perceived as 'normal' in relation to other organisations (Sataøen and Wæraas 2015).

This study indicates that the relationships within the brand architecture, where all products and services are aligned under one organisational brand, may have a slightly different role in the public sector. Rather than creating a strict hierarchy and alignment between an organisations' brands, a sense of sector-related interrelatedness between different organisations and brands may have to be considered, allowing for a sense of conformance among organisations in the sector. 
This may have implications on brand identity, as traditionally assumed perceptions may require re-examination: branding theory suggest that the core of the organisational brand is the brand identity, which "flows from the companies' superior skills and resources" (Alsem and Kostelijk, 2008). This single identity representing the organisation and its brand is generally claimed to require consistency in presentation (Dean et al, 2016; de Chernatony and Dall-Olmo Riley, 1999). While multiple identities are often argued to create confusion and to cause challenges in brand implementation, a single identity and speaking with a single voice is often challenging, not least within the complex environment of the public sector (Dholakia and Acciardo, 2014; Wæraas, 2008). This complexity materialises through a fragmented organisation with an abundance of perceptions in regards to identity and central values; in an assortment of breadth, defining a single identity proves difficult (Wæraas and Solbakk 2009). Further, as the purpose of the public sector is to serve public interest, they often face conflicting values and interests, such as having both an authoritative role to safeguard public interest and being service-oriented to meet user needs and interests (Wæraas 2008). Therefore, finding common ground rather than emphasising differences (Dholakia and Acciardo, 2014) and using the diversity of values and multiple identities have been suggested as fruitful for public organisation branding (Wæraas, 2008).

This may also support greater internal acceptance of brand values. Such acceptance is important as stakeholders develop a perception of the organisational brand through brand experiences and interactions (Dean et al, 2016; Saleem and Iglesias, 2016). Making sure that the brand values are lived and implemented in the behaviour of the organisation and people within it becomes central as "an identity can only be trustworthy if it is actually realised" (Alsem and Kostelijk, 2008). With employees becoming brand-bearers, organisations must ensure that the brand image is supported from within (Miles and Mangold, 2005). This requires developing a shared brand meaning by aligning brand values and identity with 
stakeholder perceptions (Bélanger et al, 2007). However, studies indicate that achieving a shared brand meaning may be a challenge in the public sector as the means of brand management may not be optimal (Bélanger et al, 2007) and it may also be more about tag lines, rather than a comprehensive effort to build a brand strategy (Whisman, 2009).

\section{Internal brand management}

The fundamental role of employees in branding is evident in literature, (Punjaisri and Wilson, 2011; Whisman, 2009; Aurand et al, 2005) as an organisation achieves its greatest advantage when employee actions and brand identity reinforce each other (Aurand et al, 2005).

Internal brand management is a means to supporting employee brand-related behaviour (Punjaisri and Wilson, 2011; Burmann and Zeplin, 2005). It helps align goals and values of the employee and organisation, and support employee extra-role behaviour (Matanda and Ndubisi, 2013). With a significant effect on employee brand performance, positively influencing employee brand identification, commitment, and loyalty (Punjaisri and Wilson, 2011), investing in your employees as brand bearers, is a critical step to building a strong and positive organisational brand.

Internal brand management is complex, encompassing several dimensions. At the core lies employee understanding of brand values and expectations of what is needed from them to support the brand in their behaviour (Aurand et al, 2005; Miles and Mangold, 2005).

Communicating a clear and consistent brand message to employees is essential (Aurand et al, 2005; Miles and Mangold, 2005). This needs to embrace the whole organisation where consistent brand messages are communicated through a variety of touch-points (Aurand et al, 2005). Further, dimensions such as HR support (Punjaisri et al, 2008; Mosley, 2007), leadership (Macaverty et al, 2007; Vallaster and de Chernatony, 2006), implementation of 
value systems and performance management systems (Macaverty et al, 2007; Miles and Mangold, 2005), the internal culture (Mosley, 2007; Miles and Mangold, 2005), alignment of internal and external communication (Simmons, 2009; Miles and Mangold, 2005) and aligning employee values and beliefs with organisational goals (Matanda and Ndubisi, 2013) are all central. Further, it is often said that employees will deliver the service that they themselves receive. For both the internal and the external brand, the promise must match reality (Aurand et al, 2005). Therefore, the work environment is a notable factor in enhancing employee brand attitudes in form of brand identification, commitment and loyalty (Punjaisri and Wilson, 2011), as is the role of personal interaction (Dean et al, 2016; Vallaster and de Chernatony, 2006) and dialogue (Whisman, 2009).

However, internal brand management has challenges, such as the inability of organisations to overcome functional silos involved with internal branding activity; marketing, HR, brand management, operations, front line management and strategy (Macaverty et al, 2007). Also, the brand is often not particularly integrated into work activities (Aurand et al, 2005). A lack of alignment between employee and organisational values is also considered a challenge (Macaverty et al, 2007). Brand development itself may be subject to issues as a normal topdown manner of developing the brand (Dholakia and Acciardo, 2014; Macaverty et al, 2007) is far from ideal. When a brand is not developed in a bottom-up manner, it may cause problems (Bélanger et al, 2007). Some organisations have attempted to overcome this issue by using a brand implementation process designed to gain buy-in from internal stakeholders before promoting the brand in campaigns (Dholakia and Acciardo, 2014).

\section{Brand architecture}

Brand architecture refers to how companies structure and manage the relationship between their various brands (Keller, 2015). The consensus of brand architecture literature argues that 
it is critical for the success of a company and a driver of brand strategy as it impacts upon brand extension success (Völckner and Sattler, 2006) and positive market-based performance (Talay et al, 2015). It provides clarity, synergy and leverage (Aaker, 2004) and supports understanding and organisation of the brands in the minds of customers (Keller, 2015). Brand architecture is also argued to be a means to internally help guide companies toward the future, "clarifying where it can go and how it can get there" (Keller, 2015).

Brand architecture strategies can be seen as a continuum where companies on one end can use a "branded house" strategy where all products use a core corporate name (e.g. Virgin or GE) and on the other end use a "house of brands" strategy where unique brands are managed for each product or service (e.g. P\&G) (Brexendorf and Keller, 2017). In between those two main strategies are a multitude of various hybrid versions (e.g. Polo Jeans by Ralph Lauren) (Brexendorf and Keller, 2017).

It is logical that coherent brand architecture is important to the performance of a company as it helps maximise efficient and effective use of resources, and consistency (Aaker and Joachimsthaler, 2000). Keller (2015) argues that the primary consideration in devising optimal brand architecture should be a focus on the needs of customers. However, within the public sector organisations do not have customers per se. Rather, the needs of residents, students, patients, and other external stakeholders may have to be considered, along with those of political representatives. Another aspect is that of the organisation; Strebinger (2014) argues for designing an architecture that optimises the particular needs of the company rather than being over burdened by current trends or norms in a particular sector. Brand architecture strategy therefore needs to consider both internal and external priorities; whilst an appropriate brand architecture is key for optimal external communication of the brand, it can also guide and influence internal structures and behaviours that are critical links in a coherent brand. 


\section{Brand architecture in the public sector}

The public sector arguably has much to gain from the benefits of branding, but more research is needed that relates to the branding efforts of public organisations (Watkins and Gonzenbach, 2013). It has been shown that in the public sector, some organisations are attempting to implement an umbrella brand to achieve brand harmonisation (Hemsley-Brown and Goonawardana, 2007) and transform the organisation from a 'house of brands' to a 'branded house' (Dholakia and Acciardo, 2014). However, other studies show the benefit of branding local organisations, e.g. libraries, as national branding efforts may undermine the great diversity represented by local public organisations (Hood and Henderson, 2005).

Therefore, whilst there is no accepted brand architecture approach for public organisations, it is evident that seeking an optimal structure is critical for effective branding.

Whilst brand architecture models can provide insight into sub-brands and identify potential areas of synergy or conflict; not all models suit all contexts. Brand architecture in the context of the public sector introduces a model which enables organisations to effectively manage and market the offerings it needs to. The specific model adopted needs to align with the support structures, mission and overarching strategy of the institution (Hemsley-Brown and Goonawardana 2007). The findings from this research reinforce Aaker and Joachimsthaler (2000), who suggest that the public sector follows the 'Branded House' approach in its adoption of brand architecture.

This approach is particularly evident with the case study employed in this paper as it uses a "single master brand to span a set of offerings that operate with only descriptive subbrands" (Aaker and Joachimsthaler 2000). However, the house-of-brands approach provides a certain level of autonomy to the faculties and schools. Scholars have suggested that a move towards 
the corporate system will inevitably contribute to the demise of any individuality (Gibbs, 2011; Hemsley-Brown and Goonawardana, 2007).

\section{METHODOLOGY}

This paper is based on a single case study of a large public healthcare organisation in Sweden. Case studies are a means to studying real-life issues (Silverman, 2011; Eisenhardt and Graebner, 2007), allowing researchers to highlight the rich context of the phenomenon (Eisenhardt and Graebner, 2007). The purpose of this study is to explore brand management practices and brand architecture in the public sector, from an employee perspective. The aim is therefore to gain a rich, in-depth understanding of issues and relationships rather than being quantifiably generalizable. As a relatively new topic in the context of the public sector, an inductive, case-oriented process is considered a suitable approach (Eisenhardt, 1989). Theoretical sampling could provide insights and understand relationships in regards to the context and issue (Eisenhardt and Graebner, 2007) choosing a case that is "likely to replicate or extend the emergent theory" (Eisenhardt, 1989). Therefore, the case organisation chosen is a fitting representative of a public organisation, being publically owned and financed, and being subject to substantial political influence (Perry and Rainey, 1988). In addition, the large size of the organisation enabled us to identify and understand how brand management efforts influenced brand architecture structures within the organisation. Four departments were chosen to help us explore conditions and relationships within the organisation, representing a cross-section of the organisation; one with a strategic leadership role, one within strategic development, one R\&D department and one operative department.

20 semi-structured interviews were conducted with seven managers and 14 employees. One interview with the Head of Communications also included an employee from the communications department, for a total of 21 respondents in 20 interviews. On average, the 
interviews lasted 1 hour and 13 minutes. Respondents were chosen to provide a diversity of voices, allowing us to gain a thorough understanding of the issue. We sought to explore employees' and middle managements' views on the brands as an understanding of successful branding must be grounded in an understanding of employee perceptions and relationship with the brand.

An interview guide was developed exploring themes related to branding. As the topic of public sector branding is still underdeveloped, a broad list of themes was included. The interviews were recorded and transcribed, totalling 462 single-line transcription pages.

Observations were also conducted of seven staff meetings, including weekly and monthly meetings, and bi-annual planning days. The purpose was to understand if and how brand management was integrated into the day-to-day activities and personal communication within the organisation and to gain a greater understanding of intra-organisational relationships. Field notes were taken during the observations; own reflections were included as well as documentation of discussions and statements from participants, written down as close to a citation as possible. Complementing the interviews, the observations served to strengthen the analytical process and empirical findings by comparing data from the individual interviews with group communications. The observations resulted in 57 type-written pages of memos.

The data from the interviews and observations was coded in two steps, using Nvivo. This was initiated by a line-by-line coding, staying close to the data, followed by the development and categorisation of the data (Charmaz, 2006). From this analytical process some core themes emerged relating to brand management processes in the organisation and the brand relationships within the organisation. These help to explain some key issues of brand management and brand architecture within the organisation studied. However, while it 
became obvious that departments within the organisation were involved in branding efforts, and to what extent, further analysis was required to capture its nature.

Therefore, after the initial coding process we composed a number of questions for the data (Miles and Huberman, 1994) to help us get to the core of relevant relationships in regard to the topic of study; why do employees perceive that departmental branding is important, how do employees relate to the organisational brand vision, core value statement and core values, how is the brand communicated to employees, and how do employees talk about the relationships between the parent and the departmental brand? These questions allowed us to identify and define the underlying issues of how and why individual departments are managing their brands and the relationship between internal brand management and brand architecture.

Quotes from the respondents illustrate and provide an understanding of the discourse and perceived reality within the organisation. As the interviews were held in Swedish we have been careful to ensure that the message and tone of the quote has transferred when translated into English. However, minor revisions to the quotes have occasionally been necessary to protect the integrity and anonymity of the respondents and the organisation. When this has been done we have clearly indicated such changes with front slashes; exchanging the name of the department with /department/ in the quote.

\section{FINDINGS}

\section{Brand management and architecture within the organisation}

The organisation studied is a well-known and long-established Swedish public sector brand. With a traditional top-down brand management approach, the organisation has developed an official brand in the form of a vision statement, core values statement, and core values. The 
brand values have been defined by management and then pushed through the organisation through various modes, both written and in person. However, one part of the brand values, the core values statement, was defined in collaboration with management at various levels of the organisation, i.e. with a greater level of internal influence.

Overall, the organisation aims to support clear and consistent brand communication. Organisational style guides are in place and a communications department is responsible for internal and external communication, and managing the organisational brand. Brand materials were created to support brand integration in the organisation and internal discussions about the brand values. Workshops have also been used to communicate the brand within the organisation.

It is evident that the organisation aims to build a single, consistent organisational brand, i.e. a branded house, ensuring alignment under one brand. However, interviews also reveal that the extent and consistency of the brand management may not mirror that of many private organisations. Rather, the fragmented and complex organisation makes such an effort difficult to manage; the internal diversity creates a challenging environment for defining and managing a brand that is relevant for the whole organisation:

“Well, basically, it is such a large organisation, so we don't have another view than that the organisation as a whole is influencing a pretty small part of all the communication, and it is difficult to keep track of everything that is going on." (manager)

The brand management solution has been to take a basic organisational approach to managing the brand by defining a few basic brand values with the ability to tie into all departmental roles and to develop some basic branding guidelines (a style guide) that the 
departments are expected to adhere to. Such measures are considered important to ensure consistency in promoting the brand, both from an internal and external perspective:

"There are certain rules around individual profiling and other things that the organisation must manage because otherwise, in the end, there will be departments that one almost don't know belong here, not from a resident perspective either. And that is, like, really sad because there are good stuff and this is actually a part of Ithe organisation/, which is financed by taxes, and is providing very nice things, and we want that to show." (manager)

Despite the branded house approach, interviews also uncovered that brand management is characterised by departmental autonomy where some departmental interpretation of the brand is allowed and encouraged. This means that the organisation allows individual departments to put their own 'spin' on the brand values. How this is done, and to what extent, seems to be up to each department manager. However, there is also support available from the communications department, but in a more reactive than proactive manner upon the request of the departments.

The organisational support for breaking down the brand includes brand materials that each department can use to discuss what the brand means to them. The communication department also provides internal resources to help departments develop communication plans and other activities, if support is requested. There have been attempts to hold workshops with departments to discuss how the linkage between the organisational brand and the department can be supported.

Interviews reveal attempts to integrate the brand into internal discussions and support. This is 
meant to ensure that the brand does not become 'side-tracked' (e.g. a pamphlet hidden in employees' desks) but integrated into the organisation's fabric. Further, the organisation has tried to make the brand integral to daily work life; seeing the need for integrating brand values into steering and policies. This can, for example, include connecting brand values to operational plans and goals, management recruitment criteria, and strategies for development.

However, there is also room for departments to interpret and adjust the brand values according to their role. For example, one manager explained that the core values statement did not really fit the department role. However, with some tweaking it could be adjusted for a better fit, yet keeping in line with core meaning. As one respondent explained:

"But then it is different how various departments can relate to these terms we use, what does the core values statement mean for my department, what does the vision mean for us. So the procedure is making it your own." (manager)

There are also indications that there are internal challenges to ensure a clear brand architecture structure and brand consistency in the organisation. One reason for this is a desire from departments to build and manage their own brands:

"But what I find interesting is that the desire to do their own thing is incredibly strong, but, the desire to carry the common brand, talk about the common and saying the same things, because that is what is needed to, in some way, reach all employees...that [desire] exists in so very few places, so the impact is very low." (manager)

There are also indications that the extent of the organisational brand management is subject to internal critique. In interviews, several of the respondents perceived an insufficient level of 
brand management within the organisation. This was shown in statements such as "it's not like, it is talked about on a staff meeting, really" (employee), and "but, eh, I don't know, I don't think they've done a great job" (employee) when discussing organisational branding efforts. Other respondents paint a slightly different picture, suggesting that the brand is managed, but not as extensively and as stringent as in many private companies. This is interesting as the empirical evidence also suggests that a less stringent brand management may actually be more suitable for public organisations, for reasons discussed later. Findings also indicate an internal variety in regards to brand management implementation as some middle management incorporate the brand into all work and communication, while others do not.

It should be mentioned that while branding efforts are evident in the organisation, the developed brand seems of a rather general nature. Thus, it seems to have more to do with promoting a positive perception among stakeholders rather than adhere to a traditional branding perspective of achieving a distinctive, unique, and differentiated brand.

\section{Brand elements}

The organisation uses various brand elements to represent and align the brand; it has a common organisational logo used in all communication and there are style guides in place to ensure visual conformity. Brand elements in form of various brand values expressions are also used. From the employee perspective, there are two main brand value expressions; a vision statement and a core values statement. The main modes of communication of these values, as perceived by respondents, are meetings and other gatherings, e.g. training days, and the Intranet, both mentioned by almost half the respondents as important channels of brand communication. Externally focused communication channels such as the website and 
various organisational branding materials, e.g. Powerpoint-presentations, also seem to play a role.

Surprisingly, while internal communication of the brand values seem evident, there is a difference in how employees have received them. In regards to the vision statement, employees generally seem to be aware of the vision, but do not relate to it to a great extent. While many respondents expressed their support for the brand vision; "it's pretty good, a somewhat cheeky goal to strive for" (employee), it does not show a great level of strength and commitment in the minds of employees. The reason for this is a bit unclear, but it seems like the vision statement may have failed to create a personal connection with the employees; "the vision is less important ...it has never meant very much to me" (employee). The vision statement may also be perceived as a management creation that has little or no meaning in the everyday work life of employees.

The core values statement seems to have more significance; the majority of respondents were able to recall it and seemed to relate to it to a greater extent than the vision statement. However, it was mainly one part of the core values statement that was well known among respondents and that had earned a sense of commitment. One possible explanation may be a close relationship between this value and the underlying values and motivation of why employees were attracted to the job and the sector. The other part of the core values statement was only recalled by some respondents, and was not really discussed in any length by the respondents.

The last form of brand value expression, the core values, were rarely mentioned during interviews. An interesting observation is that while the core values seemed rather unknown among respondents, the organisation has made efforts to communicate and integrate core values into the organisation. 
Thus, while it is evident that the organisation has communicated the brand values, empirical findings suggest they are not fully integrated into the organisation and the minds of employees. While some of the brand value expressions are rather well known, others aren't.

The differences between the various brand value expressions seem to originate from a number of issues. Firstly, commitment to the commonly known part of the core values statement may be less a result of successful internal branding and more a result of it being a natural part of the service performed at the organisation and core values related to the sector:

$$
\begin{aligned}
& \text { "If you look at the healthcare sector...[people] do it because you care... that, I } \\
& \text { at least, think permeates...the organisation and that is...deeply rooted...care for } \\
& \text { other people." (employee) }
\end{aligned}
$$

This desire to do good for others and society was a common issue raised during interviews. Thus, the organisation may have tapped into this motivation in a constructive way, providing what appears to be a good match between this part of the core values statement and employees' motivation for their jobs, as well as the ethos and values of the sector. This is seemingly the main brand value that has been integrated into the organisation and respondents seem to use it as a compass in their day-to-day activities. This finding is interesting as it suggests that the core of successful branding in the public sector may lie in linking the organisational brand to the values and purpose of the sector.

\section{Brand management within departments}

Empirical findings reveal that brand management is not only an issue for the organisation at large. Rather, departments show clear indications of brand management efforts, but of various levels of sophistication. These efforts include developing brand values and brand 
communication. However, in accordance with organisational style guides, all departments use the organisational logo, leaving the departmental name as the distinguishing brand element.

\section{Drivers to departmental branding}

Brand management seem to be an issue for three of the four departments included in the study. Similar to the parent brand, the branding efforts seem concerned with building a general positive perception of the department, rather than developing a unique, differentiated brand. Respondents perceive that departments have a number of internal and external stakeholders whose views of the department are important, whether financing bodies, other organisational departments, current or potential employees. If these do not have a positive perception of the department, the consequences may be severe, ranging from difficulty for departments to perform their roles, to securing staff, and even long-term survival.

From coding the interviews it can be concluded that there are various perceived benefits to managing the brand. The most common reason was to support internal clarity and pride among department employees. This emerged from a need to bring the department together as a team, repeatedly mentioned as important by respondents. Being perceived as valuable and useful was also commonly mentioned. This was seen as important because without perceived value the department would lose their position and find it difficult to perform their role in the long term. There were also two perceived benefits to branding that were less commonly discussed by respondents, but still had significance for the departments in question; for recruitment and to secure financial support. Difficulty recruiting within this sector seems to have pushed some departments towards a greater branding focus. Further, some departments, in particular those that are not part of the organisational core offering, perceived branding as an important means to their existence: 
"It is, I would argue, very important because, because if we did not have a good reputation, be well perceived, no one would want to be involved in /what we do/ and I don't think, either, did we not have a good reputation we wouldn't even exist... we have to show...our contribution is to society." (employee)

Interestingly, interviews revealed a sense of internal competition, related to securing resources, both financial and personnel. This culture, combined with the perceived benefits of departmental branding, may be pushing departments towards a greater focus on the departmental brand and may therefore have implications for the brand architecture within the organisation.

\section{The nature of departmental branding}

Interviews reveal that the main mode of departmental brand management is brand communication. However, the majority of respondents also discuss a departmental brand in form of core values and/or a brand vision. In two departments these were not necessarily in form of a formalised brand. Rather, it was expressed as a sense of 'we-ness', defining who they are as a department and how they want to be perceived by others. In another department, a formalised brand had been developed, including a departmental core statement. This was used in combination with the organisational brand. Thus, this study reveals a complex relationship between the organisational and department brands.

For brand/marketing communication purposes, two departments have developed a communications and marketing plan, one doing so with the help of the organisational communications department. While the third department did not have an official marketing plan, it was active in various branding activities. Promoting the departmental brand entails using various techniques. Personal contacts seem to be the most prominent mode of 
managing the departmental brand, e.g. study visits by stakeholders, presentations at meetings and conferences, and departmental visits to various stakeholders. These contacts make it important to gain a sense of "we-ness" and a clear understanding of the department brand to communicate a consistent and clear message to the stakeholders.

The importance of brand values were expressed by some respondents. One respondent expressed that "because the brand is, that's what we stand for, the values we have, and the work we do" (employee) and another respondent voiced similar views:

"of course it is important, sometimes you have to take a second and think about these... aspects, like what actually are our core values and, and do I practice what I preach, and do they mean anything to me or not." (employee).

In addition to personal contacts, PR and media seemed to be a common means of communication. Respondents described the various modes, including films, Facebook, contests, and newsletters. Surprisingly only one respondent discussed using the website to promote the department. This may be because all departments are under the organisational website and are not allowed to have their own.

\section{The relationship between brand management and brand architecture}

The organisation is clearly attempting to implement a branded house strategy. The organisational brand in form of name, logo, and brand values encompasses the whole organisation and all individual departments. However, there are also individual departmental branding efforts within the organisation, but without stepping outside of the branding frame set up by the organisation. Thus, while individual department branding is evident, there appears to be a close connection between the departmental and organisational brand; the two brands do not seem to compete. Rather, most respondents seem to relate easily with both 
organisational and departmental brand and with the perception of the two brands being intertwined. This is surprising as traditional brand architecture and brand management understanding suggests that internal silos and multiple brand identities tend to be detrimental for a strong organisational brand. Instead, in this organisation, the various branding efforts seem to harmonise. Some respondents even talk about how a strong brand for the department benefits the organisation at large:

"I see it as a wave, that /department/ needs to outweigh the negative...And, and I see that /department/ could do even more. And I'm also surprised that /the organisation/does not want to use us in other contexts. Because I think that we would be able to contribute and turn some, some of the negative, so we could help get others to think a bit different or act a bit different" (manager)

However, a few respondents also indicate that the fragmented nature of the organisation increases the focus on departmental branding, where the desire to take responsibility for departmental branding efforts is strong, but less so when it comes to the organisational level. This does not necessarily mean that the two brands compete, but that respondents may feel more connected to the department and its brand. This is not surprising considering the size and heterogeneity of the organisation as a whole.

Departmental branding appears accepted, even positive, as long as the brand efforts adhere to style guides and tie in with organisational brand values. However, there is a thin line between departmental branding efforts that are positive for the organisation, and those that are fragmenting the organisational brand. One respondent expresses the importance of having one common brand as not to cause confusion among external stakeholders, "being clear towards residents and patients, because I mean...we can't communicate with...1000 different messages or have 1000 different visual profiles" (employee). With that said, resistance from 
some parts of the organisation may exist, departments that would prefer being able to manage their own brand completely. A challenge therefore lies in ensuring departments to take responsibility for brand efforts that ties into the organisation at large rather than disconnect the two brands, and ensuring that all departments are committed not only to the departmental brand, but that of the organisation at large.

It should be noticed that in the three departments involved with brand management, all respondents expressed a relationship with both the organisational and the departmental brand, but with different strengths and often with a closer connection to the departmental level. The organisation as a whole is often perceived as more abstract and remote. Further, the perceived internal competition for resources also seemed to play a role in the closer relationship with the departmental level. Thus, while the organisational level is considered, everyday work life has an impact on the relationship employees develop with the brands:

"if you're a part of a larger organisation you must define your place, and that you do, as employee, very quickly and very easily, yes, it is this place of work, or it is...this department/.../These are my spaces, here's my part of the world and this is what I do." (employee)

Empirical findings suggest that there are a number of factors that could have a positive effect on the relationship between the two brand-levels:

- The core value statement

- Branding structures within the organisation

- Connections within the organisation

- Public sector values 
The core value statement: One part of the core values statement seem to be rather wellknown and accepted internally. This part may act as glue that keeps the organisational and department brands aligned. The value may not be very unique for the organisation, but fits well with the overarching purpose of the organisation and its role in the public sector. Hence, it may help bring the organisation together as a whole.

Branding structures within the organisation: The organisation has internal structures that support the relationship between the organisational and departmental brand (inc. a common logotype, website linking all departments, and a central communications department). Combined this seems to provide a common ground that interlinks all individual department branding efforts. Hence, brand management connection points within the organisation may support relationships between organisational and departmental brands while also allowing for departmental branding autonomy.

Connections within the organisation: Some respondents indicated the need for employees to gain an understanding of how departments and the organisation as a whole are interrelated. While important, this is also perceived as challenging within large, fragmented and politically managed organisations. For brand management purposes, however, it may be necessary to further integrate and connect the departments and the organisation, through such means as common policies and goal management processes. While this is, in part, already done, it does not seem to translate throughout the whole organisation.

Public sector values: The general nature of the brand values and the aim of supporting a positive and attractive image for the organisation (and individual departments), rather than branding being a means of differentiation and uniqueness, seem central to connecting the departmental and organisational brands. Public organisation may therefore need to tap into the sector purpose and values when defining and managing the organisational brand. This 
may be especially important for organisations in the public sector where the public sector ethos and values may serve as a motivational force for many employees.

\section{Challenges to the organisation-department brand alignment}

While respondents seem to relate to both the organisational and departmental brand, there are some challenges to the relationship.

One such challenge is an internal insecurity in regards to departmental branding; while considered critical, respondents also expressed an uncertainty whether departmental branding efforts were allowed within the organisation. This seems to create a sense of cautiousness in how they spoke about the departmental branding efforts in the presence of organisational representatives. One potential means of overcoming such strains on the brand relationships could be to ensure that departments are allowed to pursue departmental branding efforts. It would require that various connection points are in place, like those mentioned earlier. This could enable departments to take greater responsibility of branding efforts, while also ensuring that the department brand stays closely related to the organisational brand. However, if not managed well, this could cause greater division between the organisational and departmental brands.

A second challenge is that of departmental autonomy vs consistency of the organisational brand, where the organisation is attempting to find a balance between the two. With greater employee commitment to the departmental brand, evident in the interviews, supporting a strong brand for the organisation requires ensuring that commitment spills over into the organisational brand. How this can be done, however, is not yet clear.

A final brand management challenge concerns integrating the core values into the fabric of the organisation. Gaining acceptance and employee commitment for the brand values are 
dependent on them not only being communicated, but lived by the organisation. While some respondents suggest that the core values statement has resulted a stronger focus on those values in structures and daily work life, voices were also raised that the organisation does not always seem to live up to the promise of this statement, potentially risking undermining the brand.

\section{DISCUSSION AND CONCLUSION}

In this paper we have explored brand management and brand architecture within the public sector, with an internal perspective. A number of findings have resonance with exploration of the literature, and should be highlighted.

From a brand management perspective, this case organisation seems to adhere to a traditional approach in the form of a top-down brand development, consistency in communication, and promotion of a single organisational brand. Exploring brand architecture, our findings broadly support the view that public organisations are moving towards an umbrella brand (Hemsley-Brown and Goonawardana, 2007), that in brand architecture terms would be labelled a 'branded house' (Dholakia and Acciardo, 2014). However, within this organisation, individual departments are involved with branding efforts to promote themselves to various stakeholders for reasons identified earlier. Thus, both organisational and departmental branding efforts are evident. This does not, contrary to traditional branding knowledge, seem to have a negative influence on the organisational brand. Instead, departmental branding efforts seem, under certain circumstances, to strengthen both the organisational brand and employee brand commitment, for reasons discussed in the following paragraphs. 
In this organisation there seem to be room for departmental branding within a branded house strategy. However, findings also suggest that there is a need for a clearer and deliberate brand architecture strategy with the primary consideration on the needs of 'customers' (Keller, 2015) and the organisation (Strebinger, 2014), in this case in form of internal stakeholders. Within such a strategy care should be taken to allow flexibility to not lose diversity or strengths of parts of the organisation (Hood and Henderson, 2005). The wide assortment of services within this organisation is its strength and this needs to be preserved. By allowing individual departments to promote their brands the organisational brand as a whole may actually become stronger. This is because all departments would be promoting a positive perception for each individual part, which would be challenging for the organisation, and this could have a positive overall influence, if managed well. One conclusion of this study is therefore that a less stringent brand management approach may suffice for public organisations compared to that in the private sector. Brexendorf and Keller (2017) talk of many hybrid versions of brand architecture and the findings in this study would certainly suggest that a bespoke approach is adopted and optimum.

Further, attention has been drawn to the challenge for public organisations in finding a unique message, making public sector brands quite general and universal for their context rather than unique for the organisation (Sataøen and Wæraas, 2015). This study supports this but also suggests that it may not necessarily be as negative an issue as traditional branding wisdom suggests. This may be because the main objective may be more concerned with ensuring a general positive perception and attractiveness of the organisation rather than achieving a differentiated and unique brand. This aligns with the findings by Sataøen and Wæraas (2015) who showed the importance of public organisations being perceived as 'normal' and conforming to institutional expectations. Given the general nature of the brand, departmental 
branding may not be problematic as the departmental brands do not compete with, but rather supports the organisational brand.

The differentiated and fragmented service offering of the organisation means that while the brand is meant to provide consistency and focus, externally and internally, the complexity of the organisation is argued to make traditional, fully consistent brand management efforts difficult. By having sector-relevant, and thus rather general, brand values as an overarching focus of the organisation, departments are able to connect to brand values that are founded in their reason for existing, ensuring societal values. A second conclusion of this study is therefore that in branding public organisations the values and purpose of the sector may need to be integrated into the organisational brand values. Within such an environment departments can be allowed to take greater responsibility of interpreting the brand according to their role in the organisation while staying aligned to the meaning of the brand values. With such an approach the brand values becomes a common denominator, providing a focus and direction that departments are encouraged to dock into; a compass in employees everyday work life.

Findings in this study are also interesting when examined in the context of literature on shared understanding and brand meaning where the core competencies of the organisation should be a foundation of its brand (Dean et al, 2016; Merz et al, 2009; Ballantyne and Aitken, 2007). It is argued that in reality this may prove to be a challenge (Bélanger et al, 2007) and this study supported that view as organisational brand values were not consistently integrated in the minds of employees. This should be examined alongside the finding that perceived brand values were often more naturally part of the generic service provision rather than unique for the organisation. However, while some brand values were not integrated into the minds of employees, part of the core values statement showed a greater level of 
commitment. Comparing the commonly known part of the core values statement with the vision statement and the lesser-known part of the core values statement, it seems as if these two brand values expressions do not have the same natural connection with the sector and services provided by the organisation. The conclusion may therefore be that public organisations may have to consider sector-specific values and ethos when developing their brand values, ensuring that the sector and organisational values are intertwined.

The study also indicates that the lesser known brand values have not been integrated in the organisation to the same extent as the commonly known brand value. Arguably, these two brand value expressions could be perceived as a top management creation rather than a natural part of the day to day work activities. These may possibly not be perceived as particularly integrated into the daily work life of employees, nor having a natural connection with the organisational services. This weak relationship with brand values could have a direct impact on brand relationships among various levels within the organisation. If the organisation fails to ensure internal acceptance for the brand values they want the organisation to stand for, it will be more difficult for them to ensure that departmental branding is moving in the same direction.

However, this requires internal stakeholders to understand how the organisational and departmental brand efforts are linked. The organisation also needs to ensure certain alignment in regards to the branding efforts. Support systems in form of styleguides, marketing support, and integrating the brand into internal systems are a few ways public organisations can support a level of consistency of the brand while also providing departmental autonomy. Public organisations may need to find a balance between departmental autonomy and brand consistency as complete consistency may not be completely useful in this context. Rather, departments may need some flexibility and leeway in managing their brands. Allowing such 
practices may partly diverge from traditional branding understanding. However, greater freedom for individual departments to make their interpretation of the overarching brand and what it means for them may, perhaps surprisingly, not only ensure greater employee commitment but also improved external brand perception.

There are, however, certain connection points within the organisation that seems to have a positive influence on the department-organisational brand relationship; the core value statement, branding structures within the organisation, connections within the organisations, and public sector values. Combined, these connection points, and the general nature of the brand may, if managed well, support a strong and positive brand for the organisation.

Compared to branding in the private sector where consistency, a common brand effort, and alignment of unique brand values are a main focus (Wæraas, 2008; Mosley, 2007; Miles and Mangold, 2005), branding seemingly warrants a somewhat different approach in the public sector.

Thus, this study suggests that in the public sector individual departmental branding may be a fruitful path to building a positive brand for the organisation. Brand architecture in large, fragmented public organisations may be challenging in terms of internal brand management and brand alignment, but departmental branding efforts may mitigate this. This means of managing public sector brands may in fact contribute to a more positive organisational brand. As long as departmental brands support a positive, and sector-relevant, organisational brand, the two brands may in fact align. This study concludes that such alignment can be supported through some supporting factors linking the departmental brand efforts to the organisational brand: 
By allowing employees to take ownership of the departmental brand, organisations may increase employee autonomy and influence over their work, a positive for the work environment and likely to ensure employee brand commitment. However, this means that the brand values needs to be supported by internal structures and culture, as it is argued in studies of private sector branding (Alsem and Kostelijk, 2008; Mosley, 2007; Vallaster and de Chernatony, 2006) and facilitated through an appropriate brand architecture. Thus, it is important for organisations to ensure that the brand developed is actually integrated into the organisation, and not just empty phrases that can ultimately undermine the level of trust among employees.

In terms of wider brand management, it can be argued that findings in this study supported a need for some improvement in utilisation of brand management techniques in the public sector (Bélanger et al, 2007). However, findings also suggest that traditional brand management approaches may not always be suitable in a public sector context. Rather, public organisations may need to adapt brand practices to suit the complex nature of the sector, especially for large, diverse public organisations.

In summary, this work therefore has a number of clear contributions to literature and practice. In particular understanding of the role of branding in the public sector are notable as the work suggests that expectations and understanding of the brand need to be examined to look at positive feelings around a more generic service benefit to society, rather than pursuit of distinctiveness for its own sake. 
The need for an organisationally culture-specific brand architecture that optimises the brand as discussed is also evident. The links between this architecture and specific elements of internal and external brand management are discussed, but the complexity apparent in this work will require further empirical investigation.

The work therefore contributes across relevant fields of brand architecture and brand management in the public sector context; it provides a greater understanding of perceptions and results of the internally focused branding efforts.

\section{LIMITATION AND FUTURE RESEARCH}

While this study has provided some understanding of brand management and brand architecture in the public sector, further research is needed, as it is based on a single case study and therefore offers results that are indicative but not necessarily conclusive. As suggested, there are a number of internal structures and issues affecting the relationship between the organisational and departmental brands. More research is needed to explore how departmental branding efforts can be of benefit to the organisational brand. Further, we need to explore what conditions need to be in place to ensure that the objectives and means of branding does not compete with that of the organisation, or public sector values, but support a positive organisational brand, strengthening trust and legitimacy among stakeholders. This topic would benefit from both qualitative and quantitative studies, as the limited amount of studies warrants further in-depth explorative studies of these issues, yet also investigating to what extent the findings of this study is generalizable throughout the diversity of the public sector as a whole. 
Finally, as branding arguably seem to have some distinct underlying differences compared to branding in the private sector, further studies are needed to explore how, and to what extent, the concept of branding may need adjustment to better suit the nature of the public sector.

\section{DISCLOSURE STATEMENT}

On behalf of all authors, the corresponding author states that there is no conflict of interest. 


\section{REFERENCES}

Aaker, D.A. (2004) “Leveraging the Corporate Brand.” California Management Review 46 (3): 6-18.

Aaker, D.A. and Joachimsthaler, E. (2000) "The Brand Relationship Spectrum: The Key to the Brand Architecture Challenge." California Management Review 42 (4): 8-23.

Alsem, K.J. and Kostelijk, K. (2008) “Identity Based Marketing: A New Balanced Marketing Paradigm.” European Journal of Marketing 42 (9/10): 907-14.

Aurand, T.W., Gorchels, L. and Bishop, T.R. (2005) "Human Resource Management's Role in Internal Branding: An Opportunity for Cross-Functional Brand Message Synergy.” Journal of Product \& Brand Management 14 (3): 163-69.

Ballantyne, D, and Aitken, R. (2007) "Branding in B2B Markets: Insights from the Servicedominant Logic of Marketing.” Journal of Business \& Industrial Marketing 22 (6): $363-71$.

Balmer, J.M.T. (2010) “Explicating Corporate Brands and Their Management: Reflections and Directions from 1995." Journal of Brand Management 18 (3): 180-96.

Bélanger, C.H., Syed, S. and Mount, J. (2007) "The Make Up of Institutional Branding: Who, What, How?" Tertiary Education Management 13 (3): 169-85.

Brexendorf, T.O. and Keller, K.L. (2017) "Leveraging the Corporate Brand: The Importance of Corporate Brand Innovativeness and Brand Architecture.” European Journal of Marketing, no. August. https://doi.org/DOI: 10.1108/EJM-07-2017-0445.

Burmann, C. and Zeplin, S. (2005) "Building Brand Commitment: A Behavioural Approach to Internal Brand Management.” Journal of Brand Management 12 (4): 279-300.

Caldwell, N. and Coshall, J. (2002) "Measuring Brand Associations Fo Rmuseums and Galleries Using Repertory Grid Analysis.” Management Decision 40 (4): 383-92. 
Chapleo, C. (2006) “Barriers to Brand Building in UK Universities?” International Journal of Nonprofit and Voluntary Sector Marketing 12: 23-32.

Chapleo, C. (2010) “What Defines 'Successful' University Brands?” International Journal of Public Sector Management 23 (2): 169-83.

Charmaz, K. (2006) Constructing Grounded Theory. 1st ed. London, California and New Delhi: SAGE Publications, Inc.

Clayton, M.J., Cavanagh, K.V. and Hettche, M. (2012) "Institutional Branding: A Content Analysis of Public Service Announcements from American Universities.” Journal of Marketing for Higher Education 22 (2): 182-205.

Dean, D., Arroyo-Gamez, R.E., Punjaisri, K. and Pich, C. (2016) "Internal Brand CoCreation: The Experiential Brand Meaning Cycle in Higher Education.” Journal of Business Research 69 (8): 3041-48.

de Chernatony, L. (1999) "Brand Management Through Narrowing the Gap Between Brand Identity and Brand Reputation.” Journal of Marketing Management 15 (1-3): 157-79. de Chernatony, L. and Cottam, S. (2009) "Interacting Contributions of Different Departments to Brand Success.” Journal of Business Research 62 (3): 297-304.

de Chernatony, L. and Dall-Olmo Riley, F. (1999) “Experts' Views about Defining Services Brands and the Principles of Services Branding." Journal of Business Research 46 (2): 181-92.

Dholakia, R.R, and Acciardo, L.A. (2014) "Branding a State University: Doing It Right." Journal of Marketing for Higher Education 24 (1): 144-63.

Eisenhardt, K.M. (1989) “Building Theories from Case Study Research.” The Academy of Management Review 14 (4): 532-50.

Eisenhardt, K.M. and Graebner, M.E. (2007) “Theory Building From Cases: Opportunities And Challenges." The Academy of Management Journal 50 (1): 25-32. 
Färlin, M. (2016) "Presschefen: 'Vi vill ha en bild av vad representanter säger till media.'” Resume. https://www.resume.se/nyheter/artiklar/2016/04/27/arbetsformedlingenspresschef-vi-vill-halla-reda-pa-vad-vara-medarbetare-sager-till-media/.

Gibbs, P. (2011) “An Aristotelian Model for Ethical Higher Education Marketing: The Role of Practical Wisdom.” Journal of Marketing for Higher Education 21 (2): 203-14.

Gromark, J. and Melin, F. (2013) "From Market Orientation to Brand Orientation in the Public Sector.” Journal of Marketing Management 29 (9-10): 1099-1123.

Harris, F. and de Chernatony, L. (2001) “Corporate Branding and Corporate Brand Performance.” European Journal of Marketing 35 (3/4): 441-56.

Hatch, M.J, and Schultz, M. (2001) “Are the Strategic Stars Aligned for Your Corporate Brand?" Harvard Business Review 79 (2): 128-34.

Hatch, M.J, and Schultz, M. (2009) "Of Bricks and Brands: From Corporate to Enterprise Branding." Organizational Dynamics 38 (2): 117-30.

Hemsley-Brown, J. and Goonawardana, S. (2007) "Brand Harmonization in the International Higher Education Market.” Journal of Business Research 60 (9): 942-48.

Hood, D. and Henderson, K. (2005) "Branding in the United Kingdom Public Library Service.” New Library World 106 (1/2): 16-28.

Hudson, R. (2009) “Brand Strategy for Acute NHS Trusts.” Journal of Communication in Healthcare 2 (1): 20-33.

Hytti, U., Kuoppakangas, P., Suomi, K., Chapleo, C. and Giovanardi, M. (2015) "Challenges in Delivering Brand Promise - Focusing on Municipal Healthcare Organisations.” International Journal of Public Sector Management 28 (3): 254-72.

Keller, K.L. (2015) “Designing and Implementing Brand Architecture Strategies.” Journal of Brand Management 21 (9): 702-15. 
Macaverty, N., McQuillan, P., and Oddie, H. (2007) "Internal Branding Best Practices Study." Canadian Marketing Association June.

Matanda, M.J. and Ndubisi, N.O. (2013) "Internal Marketing, Internal Branding, And Organisational Outcomes: The Moderating Role of Perceived Goal Congruence.” Journal of Marketing Management 29 (9-10): 1030-55.

Merz, M.A., He, Y. and Vargo, S.L.J. (2009) "The Evolving Brand Logic: A ServiceDominant Logic Perspective.” Journal of the Academy of Marketing Science 37 (3): $328-44$.

Miles, M.B, and Huberman, M. (1994) Qualitative Data Analysis: An Expanded Sourcebook. SAGE.

Miles, S.J. and Mangold, G.W. (2005) "Positioning Southwest Airlines through Employee Branding.” Business Horizons 48: 535-45.

Mosley, R.W. (2007) “Customer Experience, Organisational Culture and the Employer Brand.” Brand Management 15 (2): 123-34.

Perry, J.L. and Rainey, H.G. (1988) “The Public-Private Distinction in Organization Theory: A Critique and Research Strategy.” Academy of Management Review 13 (2): $182-$ 201.

Punjaisri, K and Wilson, A. (2011) “Internal Branding Process: Key Mechanisms, Outcomes and Moderating Factors.” European Journal of Marketing 45 (9/10): 1521-37.

Punjaisri, K., Wilson, A. and Evanschitzky, H. (2008) "Exploring the Influences of Internal Branding on Employees’ Brand Promise Delivery: Implications for Strengthening Customer-Brand Relationships.” Journal of Relationship Marketing 7 (4): 407-24.

Rajagopal, R. and Sanchez, R. (2004) “Conceptual Analysis of Brand Architecture and Relationships within Product Categories." Journal of Brand Management 11 (3): 133-247. 
Saleem, F.Z. and Iglesias, O. (2016) "Mapping the Domain of the Fragmented Field of Internal Branding.” Journal of Product \& Brand Management 25 (1): 43-57.

Sataøen, L. and Wæraas, A. (2015) "Branding without Unique Brands.” Public Management Review 17 (3): 443-61.

Silverman, D. (2011) Interpreting Qualitative Data. Vol. 4th Ed. SAGE Publications, Inc. Simmons, J.A. (2009) “'Both Sides Now’: Aligning External and Internal Branding for a Socially Responsible Era.” Marketing Intelligence and Planning 27 (5): 681-97.

Strebinger, A. (2014) "Rethinking Brand Architecture: A Study on Industry, Company- and Product-Level Drivers of Branding Strategy.” European Journal of Marketing 48 (9/10): 1782-1804.

Talay, M.B., Townsend, J.D. and Yeniyurt, S. (2015) "Global Brand Architecture Position and Market-Based Performance: The Moderating Role of Culture." Journal of International Marketing 23 (2): 55-72.

Vallaster, C. and de Chernatony, L. (2006) "Internal Brand Building and Structuration: The Role of Leadership.” European Journal of Marketing 40 (7/8): 761-84.

Völckner, F. and Sattler, H. (2006) “Drivers of Brand Extension Success.” Journal of Marketing 70 (2): 18-34.

Wæraas, A. (2008) “Can Public Sector Organizations Be Coherent Corporate Brands?” Marketing Theory 8 (2): 205-21.

Wæraas, A., Bjørnå, H. and Moldenæs, T. (2015) "Place, Organization, Democracy: Three Strategies For Municipal Branding.” Public Management Review 17 (9): 1282-1304.

Wæraas, A. and Solbakk, M.N. (2009) "Defining the Essence of a University: Lessons from Higher Education Branding.” Higher Education 57: 449-62.

Westin, J. (2016) “Sekretessörja i Region Skåne.” Sveriges Radio. http://sverigesradio.se/sida/artikel.aspx ?programid=2795\&artikel=6414344. 
Whelan, S., Davies, G., Walsh, M. and Bourke, R. (2010) "Public Sector Corporate Branding and Customer Orientation.” Journal of Business Research 63 (11): 1164-71.

Whisman, R. (2009) “Internal Branding: A University’s Most Valuable Intangible Asset.” Journal of Product \& Brand Management 18 (5): 367-70. 


\section{FIGURES}

Figure 1. Brand architecture connecting points in public organisations

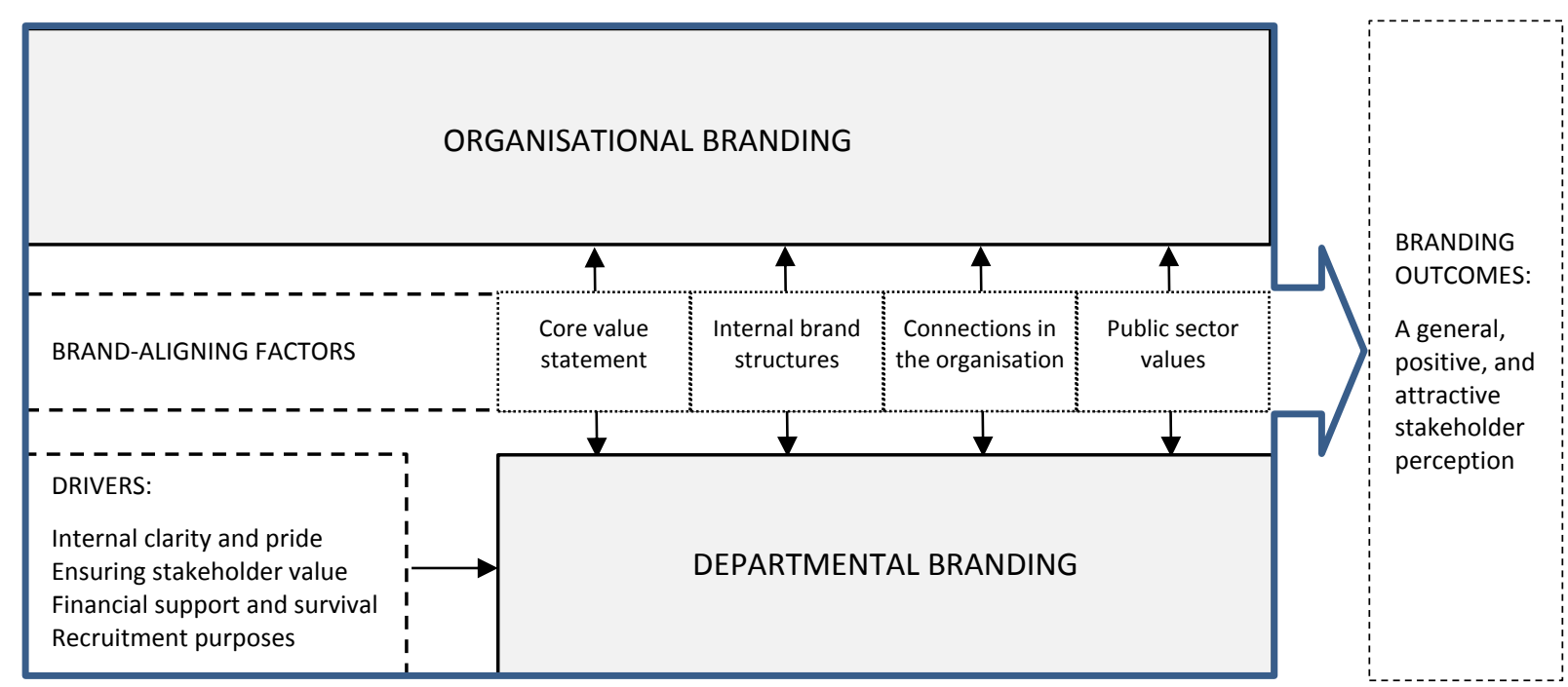

